\title{
Indonesia's Air Transportation Regulation to Prevent the Spread of Covid-19: Is It Effective?
}

\author{
Elfrida Ratnawati ${ }^{1}$, Siti Nurbaiti ${ }^{2}$ \\ \{elfrida.r@trisakti.ac.id ${ }^{1}$ \} \\ Universitas Trisakti, Jakarta, Indonesia ${ }^{1,2}$
}

\begin{abstract}
The Indonesian government issued regulations for law enforcement in an effort to suppress the spread of Covid-19, including the implementation of air transportation which is very vulnerable. Airlines as carriers are required to apply in the implementation of transportation. However, is the regulation effective in suppressing the spread of Covid-19? This article uses normative legal research supported by primary and secondary data, and is analyzed qualitatively by drawing conclusions from general to specific matters. The results show that the positive impact of implementing regulations to prevent Covid-19 is the existence of law enforcement that is applied to passengers, goods and aircraft in the process of air transportation, where passengers must carry out health protocols by conducting antigen tests through hospital referrals, washing hands, wearing masks, maintaining distance, staying away from crowds and reducing mobility, sterilization of goods is carried out by spraying drugs that kill viruses, as well as airplane rooms. There are sanctions imposed on passengers, goods and airlines if they do not implement health protocols, that is unable to carry out flight operations. The Implementation of regulations not effective yet because the passengers still lack understanding of the importance of health protocols, therefore strict supervision is needed as a preventive measure for the implementation of comfortable air transportation to a safe and productive Covid-19 community.
\end{abstract}

Keywords: Effective; Regulation; Air Transportation; Covid-19

\section{Introduction}

At the end of 2019, the whole world is facing problems with the spread of a disease caused by a virus and can spread quickly, namely Covid-19 [1]. Many countries in the world [2] have been affected by the spread of this virus, including Indonesia, which in the end the World Health Organization or WHO (World Health Organization) on March 12, 2020 announced and designated Covid-19 as a pandemic [3]. 


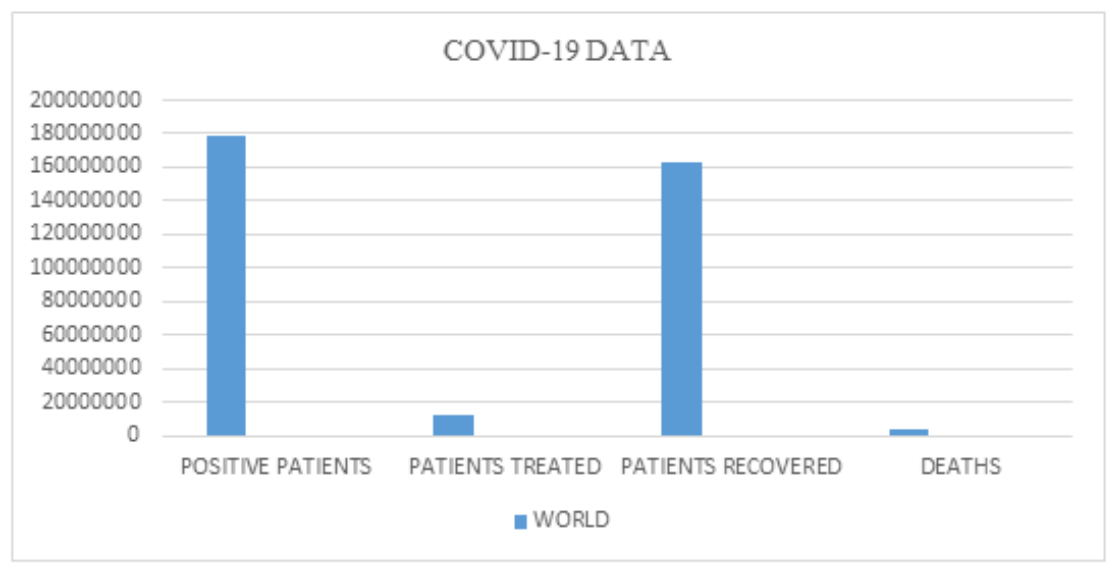

Fig. 1. Data on the monitoring of the corona virus in the world as of June 192021

This table shows data on the monitoring of the corona virus in the world as of June 19, 2021 , that are $178,575,452$ positive patients, $11,675,366$ patients treated, $163,037,556$ patients recovered and $3,866,536$ deaths [4].

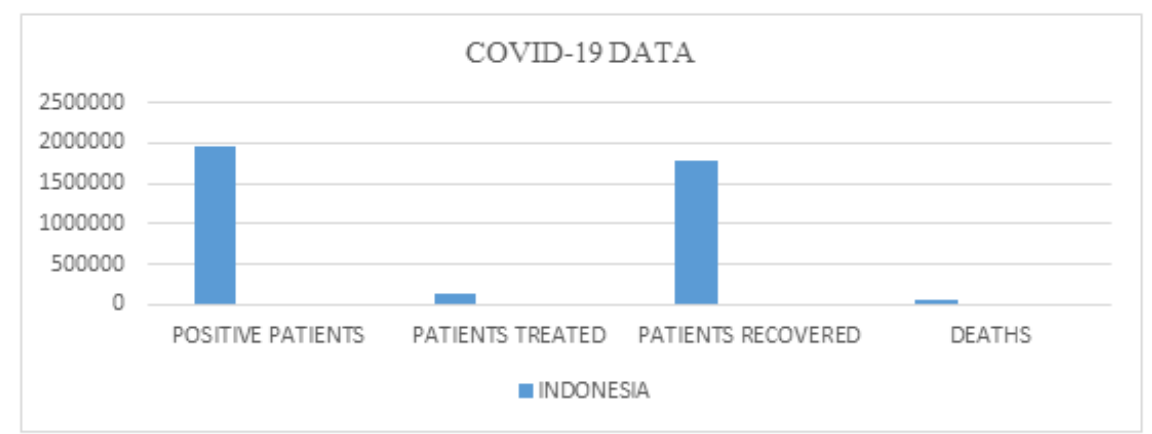

Fig. 2. Data on the monitoring of the corona virus in the world as of June 192021

This table shows data on corona virus monitoring in Indonesia as of June 19, 2021, namely 1,963,452 positive patients, 130,096 patients treated, 1,779,127 patients recovered and 54,043 deaths [5]. Based on the Central Statistics Agency, the number of domestic transportation passengers who departed in August 2020 was 2 million passengers, an increase of 36.23 percent when compared to July 2020 reaching 1.45 million, but if this data is accumulated during the period January to August 2020 as many as 21.6 million passengers, then the value decreased by 56.99 percent [6].

The Indonesian government has a way other than implementing health protocols and placing health posts around the area of air transportation flight operations [7] for the entry and exit of passengers to Indonesian territories or between regions in Indonesia in addition to issuing many regulations as law enforcement to suppress the spread of Covid-19 [8]. Just like Indonesia, air transportation in the world has made many efforts to contain the spread of Covid-19 [9], for example, at Hong International Airport in April 2021, it introduced 
mandatory Covid-19 testing, that is tourists entering Hong Kong must be sent to a testing center to be tested and wait for test results at a predetermined location. The South Korean government introduced a Covid-19 testing station with the name "walk through" at Incheon International Airport in March 2021, where medical staff will collect samples from passengers coming to the country. Then new arrivals must also download an application from the local government whose purpose is to track the location and require entrants to report any symptoms they feel. Singapore also carries out strict medical examinations for immigrants who come to visit their country [10].

In previous research, Muhammad Bilal, Suharno, and Nourma Dewi [11] tested the implementation of the Indonesian Minister of Transportation Regulation No. 18 of 2020 concerning transportation control in the context of preventing COVID-19 by using the online transportation company Grab in the city of Surakarta. The results of this study have proven that the efforts made by Grab in the City of Surakarta are following the "Regulation of the Minister of Transportation No. 18 of 2020". The thing that distinguishes this paper is that this paper only writes about regulations in the field of air transportation.

Dewi Dyah Widiastuti expressed her opinion by writing about the Inspection of Aircraft Passengers During the COVID-19 Pandemic at Halim Perdanakusuma Airport [12], and concluded that the implementation of transportation activities at Halim Perdanakusuma Airport had implemented health protocols properly.

Darwisyah Budiastuti and Alam Kurniawan, wrote about the protection of consumer rights after the cancellation of flights due to the Covid-19 virus pandemic by airlines based on the Minister of Transportation Regulation Number 25 of 2020 which regulates the prohibition of going home, which is concluded with ticket refunds [13]. Furthermore, in research by Yusti Fatmaningdyah and M Fatchoeqorib, they reviewed Air Travel Policy during the Corona virus pandemic [14]. In this study, the researchers concluded that the policies issued require an indepth study in order to benefit all parties during this covid pandemic.

The difference between the theme of the author's writing and all of the authors above is, this article will discuss air transportation regulations that have been issued by the government in responding to this covid-19 pandemic, can all the regulations issued be effective in the field? This is what will be discussed in this article, entitled: "Are Indonesian Air Transport Regulations Effective in Preventing the Spread of Covid-19?"

\section{Research Methods}

This article uses normative juridical research that examines library materials or secondary data as the basis for research, including discussing regulations issued by the government, especially in the implementation of air transportation [15], then conduct a search on the regulation, using books and literature in domestic and foreign journals that discuss regulations [16] that include synchronizing laws relating to the performance and implementation of air transportation during the COVID-19 period [17].

The nature of the research used in this paper is descriptive using secondary and primary data sources. Primary data is by conducting interviews with Air Transportation agencies and their colleagues and secondary data [18] includes regulations, official documents, books, research results in the form of reports. Then this data is analyzed qualitatively [19] and draw conclusions from general to specific about the effectiveness of air transportation regulations during a pandemic to suppress the spread of the Covid-19 virus. 


\section{Discussion}

3.1 Association of Air Transport Regulations as an Operational Standard for Air Transportation in Indonesia in relation to Covid-19

In responding to the outbreak of COVID-19 transmission in Indonesia, the government issued many regulations as a form of prevention, supervision, and law enforcement in the implementation of air transportation to prevent the spread of Covid-19. Regulations have been issued since the development of the Covid-19 virus in early March 2020, including:

1. "Regulation of the Minister of Transportation of the Republic of Indonesia Number 18 of 2020 concerning Transportation Control in the Context of Preventing the Spread of the Corona Virus," regulates in general the restrictions on activities carried out in the field of transportation modes [20];

2. "Circular Letter Number 3 of 2020 concerning Health Protocols for people traveling during the Christmas holidays and welcoming the 2021 new year during the 2019 (Covid19) coronavirus disease pandemic." This circular letter is based on the background that the spread of Covid in Indonesia is high, especially with the arrival of the year-end long holiday period, which will cause the mobility of the Indonesian population to be high. To prevent this from happening, the COVID-19 Health protocol was implemented during this long holiday, as well as general regulations regarding transportation, both land, sea, and air. Specifically, for air transportation, it was emphasized that traveling to the island of Bali, travelers are required to provide a certificate of negative results using the RT-PCR test for a maximum of $7 \times 24$ hours, while for trips to the island of Java, travelers are required to provide a certificate of negative results using a rapid antigen test at most. $3 \times 24$ hours as a travel requirement [21];

3. Letter of the Minister of Transportation Number PL.001/1/4 Phb 2020." This Ministerial Letter is issued regarding the operation of airports, ports, and other transportation infrastructure. In this letter, the Minister of transportation urges to improve the security and supervision of the movement of people and/or goods by the transportation infrastructure manager following the established Standard Operating Procedures. And implement the Health protocol to prevent the spread of coronavirus disease 2019 [22];

4. "Letter of the Director General of Civil Aviation Number HK.104/3/1/DRJU.KUM-2020 of 2020 concerning Airport Closures/Flight Restrictions. to prevent the spread of the Covid-19 virus. Important points in this letter include, among other things, that the closure of airports is the authority of the Ministry of Transportation, cq [23].

5. "Circular Letter of the Minister of Transportation of the Republic of Indonesia No. SE 19 of 2021 concerning Guidelines for the Implementation of Domestic Travel by Air Transportation During the Corona Virus Disease (Covid-19) pandemic." This circular letter was issued in connection with the issuance of the "Circular Letter of the Head of the Covid-19 Handling Task Force No. 7 of 2021 concerning the extension of travel provisions for domestic people during the coronavirus disease (covid-19) pandemic" and the need for adjustments to air transportation services. What is highlighted in this circular letter is the travel provisions for domestic people/passengers by transportation, including mandatory implementing and complying with the Health protocol (3M), not allowed to speak one way or two directions, not allowed to eat as long as less than 2 hours except for people who take medicines, meet health requirements, and fill out e-HAC at the airport of departure and show it to the airport health officer. And arrangements for air force organizers during the covid-19 period include: complying with operational provisions in accordance with the 
circular letter of the Minister of transportation number SE 13 of 2020 concerning air transportation operations, not providing food and drinks to flights less than 2 hours away, if the result of RT - The PCR of the traveler is negative but there are symptoms, the perpetrator may not continue, if the passenger returns a flight ticket, the process must comply with applicable regulations, and personnel must be obliged to show negative results using RT-PCR [24].

6. "Circular letter from the ministry of transportation, directorate general of air transportation No. SE 32 of 2020 regarding air transportation operational guidelines for the implementation of restrictions on people's travel in the context of accelerating the handling of coronavirus disease (covid-19)." This circular letter was issued in connection with the implementation of the "Circular letter of the chief executive of the COVID-19 Handling Acceleration Task Force Number 4 of 2020." The important points in this letter are air transportation operational guidelines for the implementation of restrictions on people's travel, which is carried out in synergy between the Head of the Airport Authority Office; Airport Operators, Scheduled Commercial Air Transportation Business Entities and Aviation Navigation Service Providers [25];

7. "Regulation of the Minister of Transportation of the Republic of Indonesia Number 41 of 2020 concerning Amendments to Regulation of the Minister of Transportation Number PM 18 of 2020 concerning Transportation Control in the Context of Preventing the Spread of Corona Virus Disease 2019 (COVID-19)" (Stipulated June 8, 2020, BNRI Year 2020 Number 587). This Ministerial Regulation was, of course, established to control the spread and handling of COVID-19 and to update the previous regulations. Several provisions in Permenhub Number 18 of 2020 were amended, including articles 8 and 9, with the insertion of 2 articles, namely articles $8 \mathrm{~A}$ and $8 \mathrm{~B}$. Article $8 \mathrm{~A}$ emphasizes that transportation control in Article 3 is carried out based on technical guidelines and instructions for the implementation of land, sea, air, and rail transportation. Article 8B emphasizes sanctions in the form of administrative sanctions in the form of written warnings, suspension of permits, revocation of permits and administrative fines carried out in accordance with statutory regulations. The provisions of the amended articles, plus article 11, article 12, article 13, article 14, article 14A, essentially emphasize the control of car, motorcycle, river, lake, and crossing, rail, sea and air transportation activities. load capacity and total seating capacity with the implementation of physical distancing. The limitation on the number of passengers on the above transportation means is determined by the Minister. Article 22A is inserted which essentially reads the Minister, Commander of the Indonesian National Armed Forces, National Police Chief, Governor, Regent/Mayor, central and regional task forces for the acceleration of handling COVID-19, technical implementing units of the Ministry of Transportation, and other transport operators in accordance with their authority to carry out socialization, control, and supervision of this ministerial regulations.

8. "Ministry of transportation circular letter No. SE 12 of 2021 concerning Instructions for the implementation of international travel by air transportation during the corona virus disease (covid-19) pandemic [26]. " This circular letter was issued in connection with the stipulation of the "circular letter of the chairman of the task force for the implementation of covid-19 Number 6 of 2021 concerning the Health protocol for international travel during the 2019 Coronavirus disease pandemic as well as adjustments to air transportation services." This circular contains several important points, that is: temporarily closing the entry of foreigners from all countries to Indonesia, Indonesian citizens from abroad must continue to carry out the health protocols set by the government and foreign nationals who 
travel internationally are not allowed to enter Indonesia unless the holder Service and Diplomatic Visas;

9. "Instruction of the Minister of Transportation of the Republic of Indonesia Number IM 3 of 2021 concerning Monitoring and Evaluation of Transportation Courts during the Eid alFitr $1442 \mathrm{H}$ period in the context of preventing the spread of COVID-19" This instruction was issued to follow up "Regulation of the Minister of Transportation Number PM 13 of 2021 concerning control of transportation during the Eid al-Fitr $1442 \mathrm{H}$ period in order to prevent the spread of covid-19 and the circular of the task force for handling covid-19 number 31 of 2021." The contents of this instruction are to monitor and evaluate transportation control activities by:

a) Report data on passengers, goods, facilities, and infrastructure for land, sea and air transportation.

b) Coordinate with relevant agencies

c) Conducting socialization and supervision of transportation control during Eid $1442 \mathrm{H}$

10. "Regulation of the Minister of Transportation of the Republic of Indonesia Number PM 13 of 2021 concerning transportation control during the Eid al-Fitr period in $1442 \mathrm{H}$ in the context of preventing the spread of the 2019 corona virus disease [27]." This Ministerial Regulation was issued to control transportation during the Eid al-Fitr period in $1442 \mathrm{H}$ in the context of the spread of Covid-19 by prohibiting the use or operation of transportation facilities used for going home. For air transportation, Article 20 prohibits the use or operation of air transportation, but not for everyone there are some exceptions as regulated in Article 21, and for the result of flight cancellation, business entities must return ticket fees to prospective passengers. As regulated in article 26 and how to return it is regulated in article 27 of the ministerial regulation.

11. "The Circular Letter of the Ministry of Transportation of the Republic of Indonesia No. SE 34 of 2021 concerning amendments to the Circular Letter of the Minister of transportation number SE 26 of 2021 regarding the instructions for carrying out domestic travel by air transportation during the COVID-19 pandemic [28]." This circular letter is a change made to the circular letter of the Minister of transportation Number SE 26 of 2021 which adds an important point, namely the provisions of number 3 letter $d$ of the previous circular letter, namely the addition of "especially in the period leading up to the homecoming period which is valid from April 22 to May 5, 2021 and after the homecoming period which is valid from May 18 to May 24, 2021, it is mandatory to show a certificate of negative results from the RT-PCR test or rapid antigen test which was sampled 1 x 24 hours before departure or a negative result of GeNose C19 in within 1 x 24 hours before departure.

\subsection{Attitudes of the World and Indonesian Aviation Industry Responding to Covid-19.}

The spread of the Covid-19 Virus around the world has a huge impact on the aviation industries [29]. Health protocol [30]. To respond to the corona virus in the aviation sector, the International Air Transport Association (IATA) has also issued several programs, that are:

1. IATA Travel Pass Initiative, which is to reopen borders without quarantine and restart flights, the government must believe that there is an effort to reduce the risk of the spread of covid-19, by knowing accurate passenger data. Through the IATA Travel Pass Initiative, it contains what information passengers need about the tests, vaccines, and other measures they need before traveling, details on what and where they can be tested, and 
gives them the ability to share their test and vaccination results safely and protect them. their privacy

2. COVID-19 Contingency Related Differences (CCRD) is very necessary for urgent needs aimed at reducing the risk of the covid-19 pandemic through air transportation, in operational safety measures giving airlines greater flexibility while maintaining the safety of passengers and flight crew. Some of the steps of these preventive purposes must be submitted to ICAO (International Civil Aviation Organization), these include: Validity of personnel licenses, ratings, certificates, and endorsement of aircrew, instructors, inspectors, aircraft maintenance licensees, and air traffic controllers

3. COVID-19 Dashboard on State \& Airport Restrictions. The COVID-19 pandemic has caused a major shock in aviation operations, with various airport restrictions. To support airlines in their operations, IATA has developed an interactive dashboard containing information about the latest FIR (Flight Information Region), airport and State restrictions posted via NOTAM (Notice to Airmen) and AIS (Aeronautical Information Service) data. This data is based on publicly available information.

4. COVID-19 Government Public Health Mitigation Measures. This contains a list of countries regarding public health requirements related to COVID-19 that passengers and airline crew must follow at the airport and on board. This information is compiled from official government sources.

5. COVID-19 Travel Regulations Map. This map contains information on COVID-19 travel regulations. This information is sourced from IATA's partnership with airlines as well as developing bilateral relations with government agencies around the world

6. Safely Reopening Borders. This program is against the backdrop of the worsening economic and social impact of the COVID-19 pandemic, and the urgent need to reopen borders, and allow international travel to continue with the start of the COVID vaccination program.

7. Safely Restarting the Aviation Industry. To safely restart aviation systems, airlines and their supply chain partners (airports, ANSPs, ground handlers) must be prepared and meet regulatory requirements to resume and maintain operations during recovery.

ICAO also issued a special regulation, namely Guidance for Air Travel through the COVID-19 Public Health Crisis. This document provides a framework for addressing the impact of the current COVID-19 pandemic on the global aviation transportation system. The annex to this document includes the necessary mitigation measures to reduce public health risks to air passengers and aviation workers while strengthening trust among the traveling public, aviation workers, global supply chains and governments. Here are five flight rules that have begun to be used during the corona virus pandemic [31]:

1. Each airline makes internal rules, namely emptying the middle seat, because based on the results of research at the Massachusetts Institute of Technology estimates, emptying the middle seat will also reduce the risk of being infected with the Covid-19 virus; Jumlah penumpang diminimalkan agar interaksi lebih sedikit [32];

2. Inflight services such as food service, newspapers are temporarily suspended;

3. Must and must wear masks, IATA states that time members and passengers are required to use a master to minimize transmission;

4. IATA states that they must carry out Covid-19 testing, during the travel period, to the airport, while on the plane until they get out of the plane.

\subsection{Are the regulations implemented by the government effective?}


To find out whether the regulations issued by the Government in the field of air transportation have been running effectively or not and are there any obstacles faced? The authors will start from theme selves, because he often travels out of town to carry out work and some of the consumers who use airline services that the author meets and ask directly about the implementation of regulations in the aviation industry and what things are faced by these consumers.

When you want to order departure tickets on each airline, offers are available whether ticket bookings include an Antigen test at a Hospital or Health Clinic in collaboration with the Airline or do it yourself, because this is to make it easier for consumers. After making a choice, if the choice includes an antigen test, then a hospital or clinic will be referred by providing information on addresses that consumers can choose from in their nearest or known area. Arriving at the Hospital or Clinic, an examination will be carried out, and wait for the test results to come out. So far, the author has not faced any obstacles and the process is very good and fast. This is also felt by other consumers who were interviewed by the author when they headed to Samosir City via Halim Perdanakusuma Airport to Silangit and through Soekarno Hatta.

The Health Protocol is carried out strictly and according to standard procedures, but according to the results of the author's interview with a consumer who was traveling to the West Kalimantan region, he encountered problems, because consumers did not order tickets at the same time as the health test offer. Arriving at Soekarno Hatta Airport, consumers are asked for proof of having taken a health test, and given an antigen test, but the airline staff refuses because the requirement to arrive in the West Kalimantan area must use a PCR Swab test. This confuses consumers and ends up canceling their flights with tickets that cannot be rescheduled [10]. The results of interviews with several consumers, obtained information, that the health protocol is carried out by consumers after reading, understanding and understanding the regulations issued by the Government, and the opposite will be found if they do not know the regulations, which may be caused by not reading and lack of accurate information about the implementation health protocols when carrying out activities using air transportation.

In addition, there must be an affirmation of the existence of sanctions for parties who do not comply with the health protocol in the airport area, because there is still no awareness of the parties in maintaining health for themselves and other parties obtained by the author during activities using air transportation, namely when verifying the completeness of documents as a condition for the check-in process, where there is no awareness from consumers to queue and maintain distance, even paying attention to what is emphasized in the form of announcements when entering the airport about health protocols, then boarding, and even when landing, it has been announced by the flight attendants that they will be called based on the row of seats, but because they want to leave quickly, so they do not pay attention to health protocols, namely cramming and not keeping a distance from each other, and no sanctions have been strictly applied so far. All regulations issued by the Government have one goal, namely to change the behavior of the Indonesian people to obey the applicable laws. Regulation is enforced as law enforcement, and people must obey the rule of law.

\subsection{Steps for Air Transport Regulations to Effectively Suppress Covid-19}

As stated above, from the Central Statistics Agency or BPS, there has been a decline in the number of passengers in the aviation sector, both domestic and international. Based on this, the Indonesian government has issued a number of regulations to control the spread of Covid19, especially in the aviation sector, which regulates health protocols for flight travel. The 
implementation of regulations for handling Covid-19 in the aviation sector poses challenges for policy makers, airport operators, airlines, and the public [33].

The challenges for regulators include determining the suitability of cross-sectoral policies and responding responsively to the developments of the Covid-19 case, therefore it is necessary to strengthen governance and regulations in the aviation sector and based on qualitative and quantitative studies of aviation sector regulations in order to achieve results and impacts. In an effective way to suppress the spread of Covid-19 in the implementation of flights, every regulator and operator in the aviation sector must build a vision and coordinated action by prioritizing collaborative cooperation in its implementation in the field.

The regulations made must be in line with the basic values of the state or the Grundnorm contained in the Preamble to the 1945 Constitution. Regulations must be in accordance with the hierarchical structure of the legislation as stated in the provisions of Article 7 paragraph (1) of Law Number 12 of 2011 concerning the Establishment of Legislation, which aims to ensure that there is a conformity of regulations that are integrated with each other [34].

Regulations must include the values of law enforcement and justice in accordance with the constitutional mandate. In this case, the value of justice is seen from the aspect of stakeholders as air transportation service business actors, both the airlines themselves and their supporters [34]. The policies issued are in the form of limiting the number of passengers, hampering the convenience or access of consumers to use flight services which can cause financial losses and other sectors [35]. The government must balance policies by considering the policies issued, such as being able to make it easier for air transportation services, both fiscal and non-fiscal, because the impact felt by the aviation industry is very heavy, so the government should also pay attention to the implementing parties of the aviation industry by making regulations that balance the state of the flight industry due to Covid-19 such as doing tax relaxation, reducing landing costs, aircraft parking fees, regulating ticket tariff policies [36], and promotion of air transportation services by carrying out safe, simple, efficient and easy Covid-19 procedures but still having high security standards; The implementation of regulations must be coordinated between the Ministry of Transportation and the implementation of regulations must be coordinated between the Ministry of Transportation and the Regional Government, Airport Operators, and Airline Companies. In addition, coordination is also carried out with various stakeholders so that the implementation of regulations can be aligned between the Ministries and other institutions and units responsible for handling the Covid-19 outbreak, that is the Regional, Central Government, Ministry of Home Affairs and Ministry of Health.

The regulations issued must refer to the policy standards that have been issued by the World Health Organization (WHO), namely the International Health Regulation 2005 (IHR 2005). In addition, the Ministry of Transportation must obtain a benchmark as a comparison for various international policies issued by international civil aviation institutions, international civil aviation associations, such as ICAO, IATA, and others. National regulations that apply in Indonesia include the Regulation of the Minister of Transportation Number 18 of 2020 and Regulation of the Minister of Transportation Number 41 of 2020 which regulates health procedures and protocols that must be met by transportation users, transportation operators and crew of facilities, starting from the beginning of the trip, on the way. and arrive at the destination. The main principle of this regulation is ensuring the application of the use of masks, psysical distancing (keeping a distance) and maintaining hand hygiene, both with soapy water and/or hand sanitizer. Physical distancing in this regulation is applied to aircraft and air transportation infrastructure, where the capacity for aircraft is limited to $70 \%$ of the total capacity [37]. 
Law Enforcement or Law Enforcement to overcome the lack of awareness in complying with enforced regulations that have been enforced starting from before passengers enter the airport, during flight and at the next airport to enter the aircraft. This law enforcement effort is carried out as an effort to prevent and ensure the implementation of health protocols that must be enforced for both airport and aircraft operators; It is necessary to ensure that in implementing the health protocol there must be adequate facilities, infrastructure and infrastructure supported by human resources for its implementation, such as the availability of health checkpoints, which function to check passengers who will enter the airport;

Health checks are mandatory for every passenger, so far, the technique for implementing the examination that has been running well and effectively is through the PCR Swab Test, which requires time and money, besides the Antigen test. In this case, airlines facilitate health checks in collaboration with hospitals that provide these facilities. There must be information disclosure because it will increase understanding and discipline for passengers in carrying out the contents of regulations issued by the government. Therefore, information must be provided to airport operators, airlines, regulators regarding flight conditions, service procedures during flights, health protocol standards and post-flight information;

The creation of an integrated document inspection system, why? Because if the inspection is done manually in the form of a passenger queue, then the process of risk of transmission will occur, so a new innovation must be carried out, to minimize the risk of transmission, namely barcode technology, which can keep traces of passenger history, and at Indonesian airports it is known as E-Hac.

An exclusive partnership between two countries must be carried out, for example, currently several countries carry out quarantine obligations for both foreigners and their own citizens, between 14 days. Indonesia as an archipelagic country does this by restricting it strictly through provincial or island borders, as is currently the case in East Java which is currently in the Red Zone, between Surabaya and Madura, where residents who want to leave the Madura area must perform a PCR Swab and then test again.

\section{Conclusion}

Regulations in air transportation are implemented so that people can be safe, comfortable, and healthy in carrying out their activities. The implementation of regulations to suppress the spread of Covid-19 is not effective. So, for the regulation to be effective, the public must know regulatory information, understand and implement it with the awareness that health is important for themselves and others, thus, the spread of Covid-19 can be suppressed. In addition, there must be sanctions as a deterrent effect if they do not carry out the contents of the regulations applied in activities using air transportation. The government as a regulator must be able to synchronize regulations properly and in its implementation can synergize with other regulators so that it runs in balance and harmony.

The spread of Covid-19 can be suppressed if there is a high awareness of air transportation users to implement the health protocols outlined in the regulations issued by the Government. So, the implementers of regulations, that is air transportation users, should be able to read, understand and comply with and carry out the contents of Government regulations, and there must be strict sanctions applied by the Government so that the public can carry out the contents of the regulations. 


\section{References}

[1] C. Zhu, J. Wu, M. Liu, L. Wang, D. Li, and A. Kouvelas, "Recovery preparedness of global air transport influenced by COVID-19 pandemic: Policy intervention analysis," Sci. Direct Transp. Policy, vol. 106, 2021.

[2] J. Arellana, L. Ma'rquez, and V. Cantillo, "COVID-19 Outbreak in Colombia: An Analysis of Its Impacts on Transport Systems," Hindawi J. Advence Transp., vol. 20, 2020.

[3] J. A. Calderon-Tellez and M. M. Herrera, "Appraising the impact of air transport on the environment: Lessons from the COVID-19 pandemic," Sci. Direct Transp. Res. Interdiscip. Perspect., vol. 6, 2020.

[4] "Corona Virus Monitoring Data." https://www.worldometers.info/coronavirus/ (accessed Jun. 19, 2021).

[5] "Corona Cases in Indonesia." https://www.worldometers.info/coronavirus/country/indonesia/ (accessed Jun. 19, 2021).

[6] Herman, "Badan Pusat Statistik (BPS): Penumpang Angkutan Udara Domestik Alami Tren Kenaikan,” 2020. https:/www.beritasatu.com/ekonomi/682645/bps-penumpangangkutan-udara-domestik-alami-tren-kenaikan (accessed May 01, 2021).

[7] I. G. P. Mastra, Pokok-Pokok Pengelolaan Jasa Kebandarudaraan. Jakarta: Mitra Wacana Media, 2013.

[8] R. Aditya, "Tanggung Jawab Bandara dan Maskapai Penerbangan di Tengah Pandemi," Hukum Online, 2020. https://www.hukumonline.com (accessed May 20, 2021).

[9] X. Sun, S. Wandelt, and A. Zhang, "On the degree of synchronization between air transport connectivity and COVID-19 cases at worldwide level," Sci. Direct Transp. Policy, vol. 105, 2021.

[10] M. Arnani, "5 Aturan Penerbangan yang Berubah sejak Pandemi Virus Corona," 2020. https:/www.kompas.com/tren/read/2020/08/02/130000565/5-aturan-penerbanganyang-berubah-sejak-pandemi-virus-corona?page=all (accessed May 07, 2021).

[11] M. Bilal, . Suharno, and N. Dewi, "Pelaksanaan Peraturan Menteri Perhubungan RI No. 18 Tahun 2020 tentang Pengendalian Transportasi dalam Rangka Pencegahan Covid 19," J. Supremasi, vol. 11, no. 1, pp. 115-129, 2021, doi: 10.35457/supremasi.v11i1.1316.

[12] D. D. Widyastuti, "Pemeriksaan Penumpang Pesawat Udara Pada Masa Pandemik Covid-19 Di Bandar Udara Halim Perdanakusuma," J. Mitra Manaj., vol. 12, no. 1, pp. 53-60, 2021, [Online]. Available: https://journal.universitassuryadarma.ac.id/index.php/jmm/article/view/633/604.

[13] D. Budiastuti and A. Kurniawan, "Perlindungan terhadap Hak Konsumen dalam Kaitan dengan Pembatalan Jadwal Penerbangan Selama Masa Pandemi Virus Corona The Protection toward Consumer Rights in Dealing with Cancellation of Flight Schedule during Corona Virus Pandemic Period," vol. 5, no. 1, pp. 109-119, 2021, [Online]. Available: http://ojs.uho.ac.id/index.php/holrev/article/download/12808/11503.

[14] Y. Fatmaningdyah and M. Fatchoelqorib, "Kebijakan Perjalanan Udara di Masa Pandemi Corona Virus (Covid-19)," Aviasi J. Ilm. Kedirgant., vol. 17, no. 1, 2020, [Online]. Available: https://ejournal.stp-aviasi.ac.id/index.php/JIK/article/view/56/pdf.

[15] I. G. P. Mastra, Manajemen Transportasi Udara, Pokok-Pokok Penyelenggaraan Bisnis Jasa Angkutan Udara. Jakarta: Mitra Wacana Media, 2016. 
[16] M. Hingun and R. Mohamed Nizamuddin, "Amending section 84 patents Act 1983 to encompass the health flexibilities leverage accorded by article 31 bis Trips agreement," UUM J. Leg. Stud., vol. 11, no. 2, pp. 1-26, 2020.

[17] "Manfaat Tol Laut Mempercepat Pembangunan," 2015. http://www.presidenri.go.id/ (accessed Jun. 17, 2020).

[18] S. Ek. Pribadi, "Mimpi Tol Laut Sudah Terwujudkah?," Kompasiana, 2019. https:/www.kompasiana.com/sigit19781986/5cb47603a8bc1540a03b31d2/mimpi-tollangit-sudah-terwujudkah (accessed Dec. 20, 2019).

[19] D. O. Susanti and A. Efensi, Penelitian Hukum. Jakarta: Sinar Grafika, 2014.

[20] Permenhub No. 18 Tahun 2020 tentang Pengendalian Transportasi dalam Rangka Pencegahan Penyebaran Corona Virus Disease 2019 (COVID-19). 2020.

[21] Surat Edaran No. 3 Tahun 2020 tentang Protokol Kesehatan Perjalanan Orang Selama Libur Hari Raya Natal \& Menyambut Tahun Baru 2021 dalam Masa Pandemi Covid-19. .

[22] Surat Menteri Perhubungan Nomor PL.001/1/4 Phb 2020 Tentang Penyelenggaraan Bandar Udara. 2020.

[23] Surat Dirjen Perhubungan Udara Nomor HK.104/3/1/DRJU.KUM-2020 Tahun 2020 Tentang Penutupan Bandara/Pembatasan Penerbangan. 2020.

[24] Surat Edaran Menteri Perhubungan Republik Indonesia No. SE 19 Tahun 2021 tentang Pedoman Penyelenggaraan Perjalanan Domestik Dengan Angkutan Udara Selama Pandemi Corona Virus Disease (covid-19). 2021.

[25] Surat Edaran Kementerian Perhubungan, Ditjen Perhubungan Udara Nomor SE 32 Tahun 2020 tentang Petunjuk Operasional Perhubungan Udara Untuk Penerapan Pembatasan Perjalanan Orang Dalam Rangka Percepatan Penanganan Penyakit Virus Corona (Covid-19). 2020.

[26] Peraturan Menteri Perhubungan Republik Indonesia Nomor 41 Tahun 2020 tentang Perubahan Atas Peraturan Menteri Perhubungan Nomor PM 18 Tahun 2020 tentang Pengendalian Transportasi Dalam Rangka Pencegahan Penyebaran Corona Virus Disease 2019 (COVID-19). 2020.

[27] Surat Edaran Kementerian Perhubungan No. SE 12 Tahun 2021 tentang Pedoman Penyelenggaraan Perjalanan Internasional Melalui Angkutan Udara Selama Pandemi Corona Virus Disease (Covid-19). 2021.

[28] Instruksi Menteri Perhubungan Republik Indonesia Nomor IM 3 Tahun 2021 tentang Pemantauan dan Evaluasi Keadilan Transportasi Selama Idul Fitri 1442 Hijriah Dalam Rangka Pencegahan Penyebaran COVID-19. 2021.

[29] Peraturan Menteri Perhubungan Republik Indonesia Nomor PM 13 Tahun 2021 tentang Pengendalian Transportasi Selama Idul Fitri 1442 H Dalam Rangka Pencegahan Penyebaran Penyakit Virus Corona 2019. 2019.

[30] Surat Edaran Kementerian Perhubungan Republik Indonesia Nomor SE 34 Tahun 2021 tentang Perubahan Surat Edaran Menteri Perhubungan Nomor SE 26 Tahun 2021 Tentang Petunjuk Pelaksanaan Perjalanan Domestik Melalui Angkutan Udara Selama Masa Pandemi COVID-19. 2021.

[31] L. Budd and S. Ison, "Responsible Transport: A post-COVID agenda for transport policy and practice," Sci. Direct Transp. Res. Interdiscip. Perspect., vol. 6, 2020.

[32] P. W. Hutapea, "Perlindungan Hukum Bagi Pengguna Jasa Penerbangan di Tengah Pandemi Covid-19," Jurist-Diction, vol. 4, no. 3, p. 1085, 2021, doi: 10.20473/jd.v4i3.26984.

[33] A. Sinilele, "Perlindungan Hukum Terhadap Penumpang Pada Transportasi Udara 
Niaga Pada Bandara Sultan Hasanuddin Makassar," Al Daulah J. Huk. Pidana dan Ketatanegaraan, vol. 5, no. 2, pp. 191-212, 2016, doi: 10.24252/ad.v5i2.4806.

[34] G. I. Yuristiana, “Analisis Kebijakan Tarif Dalam Transportasi Udara Di Indonesia (Tinjauan Terhadap Tarif Batas Atas Dan Tarif Batas Bawah Penumpang Kelas Ekonomi Rute Penerbangan Domestik) TESIS," Universitas Tarumanegara, 2021.

[35] R. M. D. M. Darmawansyah, "KOLABORASI SURVIVE PEMERINTAH DAN MASKAPAI GARUDA INDONESIA DALAM UPAYA PEMULIHAN PEREKONOMIAN NEGARA DI MASA PANDEMI," Acad. Edu, 2021, Accessed: May 02, 2021. [Online]. Available: https://www.academia.edu/download/66148926/KOLABORASI_SURVIVE_PEMERI NTAH_DAN_MASKAPAI_GARUDA_INDONESIA_DI_MASA_COVID_19.pdf.

[36] T. Fahira, "SINKRONISĀSI DAN HARMONISASI PERATURAN MENTERI PERHUBUNGAN NOMOR 18 TAHUN 2020 TENTANG PENGENDALIAN TRANSPORTASI DALAM RANGKA PENCEGAHAN PENYEBARAN CORONA VIRUS DISEASE 2019 (COVID-19)," Universitas Islam Negeri Syarif Hidayatullah Jakarta, 2021.

[37] E. Prasojo et al., "Efektivitas Regulasi Penerbangan pada Masa Pandemi COVID-19," Policy Br. DISTP UI, pp. 1-4, 2020, [Online]. Available: https://distp.ui.ac.id/wpcontent/uploads/2020/11/01-Policy-Brief_UI_Efektivitas-Regulasi.pdf. 